\title{
Procurement policy and SME participation in public purchasing
}

\author{
Bernard Hoekman (1) B Bedri Kamil Onur Taș
}

\begin{abstract}
This study investigates the relationship between regulatory policies governing public procurement and participation by small and medium enterprises (SMEs), using a large dataset on European procurement. We find that better quality procurement regulation is associated with greater SME participation and higher probability that SMEs win contracts. Dividing contracts into smaller lots, a key feature of 2014 EU procurement regulation reform, bolsters participation by SMEs but only increases the probability of SMEs winning contracts for small value lots ( $€ 25,000$ or less). Our results suggest governments seeking to enhance participation by SMEs in public procurement without explicitly favoring SMEs can do so by improving the overall quality of procurement processes.
\end{abstract}

JEL classifications $\mathrm{L} 26 \cdot \mathrm{H} 57 \cdot \mathrm{O} 12$

B. Hoekman

Robert Schuman Centre for Advanced Studies, European

University Institute, Via Boccaccio, 121, 50133 Florence, Italy

B. Hoekman $(\bowtie)$

Centre for Economic Policy Research, London, United Kingdom e-mail: bernard.hoekman@eui.eu

B. Hoekman • B. K. O. Taș

Economic Research Forum, Cairo, Egypt

B. K. O. Taş

e-mail: onurtas@etu.edu.tr

B. K. O. Taş

TOBB ETU, Sogutozu cad. 43, 06560 Ankara, Turkey
Keywords Public procurement - SME participation . Good practice $\cdot$ Regulation $\cdot$ Lot size

\section{Introduction}

Public procurement (PP) generally represents a significant share of aggregate GDP. In the European Union (EU), PP represents $13.3 \%$ percent of total EU GDP, with public authorities spending some $€ 2$ trillion per year during the 2015-2017 period on the purchase of services, works, and supplies (European Commission 2019). Most countries have put in place legislation that regulates the process through which public contracts for goods, services, and works are allocated. These generally seek to assure "value for money" and accountability for the outcome of contract award decisions. In the EU, specific directives define in some detail how procuring government entities - both EU institutions and at the member state level - must behave when undertaking public procurement that exceeds certain threshold values. The basic principles include competition, nondiscrimination, and transparency.

Procurement regulation that reflects primarily "value for money" considerations may skew the allocation of contracts to large firms that are better able to incur the costs associated with procurement processes and satisfy criteria that are used to ensure bidders have the capacity and track record to implement a contract. Because smalland medium-sized enterprises (SMEs) ${ }^{1}$ constitute most

${ }^{1}$ The OECD defines SMEs as medium-sized firms that employ between 50 and 250 workers, small firms with 10-49 employees, and micro firms with fewer than 10 employees 
firms in any economy (Ayyagari et al. 2007), many governments have sought to address this potential bias and ensure that SMEs are able to participate in public calls for tender. SMEs generally confront various constraints, ranging from access to finance to limited human resources (Beck and Demirgüç-Kunt 2006), that may impede their ability to satisfy both the administrative and substantive requirements associated with PP processes, dissuading them from competing for public contracts. Reflecting this, many countries have introduced measures into public procurement regimes that aim to support SME participation. These may explicitly favor SMEs through provisions such as price preferences, earmarking a minimum share of total procurement or specific contracts to SMEs, or requiring winning bidders to sub-contract to SMEs. ${ }^{2}$ Alternatively, they may focus on facilitating SME participation in PP through generally applicable measures that aply to all tenders, such as simplification of procedures, bid eligibility requirements that are feasible for SMEs to satisfy, and limiting the size of contracts.

In this article, we analyze the second type of policy. We ask whether generally applicable PP regulation aimed at fostering SME participation in PP has this effect. This research question is answered using detailed data on public contracts awarded in 32 European countries in 2016 and 2017. Specifically, we examine the relationship between SME participation and the "quality" of PP regulation, measured by how closely national regimes align with internationally accepted good practice. We also assess the role of contract size and subdivision of contracts into smaller lots, a key feature of the 2014 EU PP policy reform aimed at enhancing SME participation in PP. ${ }^{3}$ Our interest is to investigate whether the quality of PP regimes affects participation in public tenders by SMEs and the likelihood of their success in winning contracts and to estimate the relationship between average contract size and the probability of SMEs winning tenders. We can do so because the

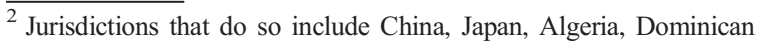
Republic, Morocco, Kenya, and the United States (Nielsen 2017). US federal procurement law gives preferences for small businesses owned by women and firms based in or owned by businesspeople from socially disadvantaged groups

${ }^{3}$ The 2014 EU directive on public procurement requires procuring entities to consider splitting contracts into lots and to justify the reasons for decisions not to do so. Such subdivision into lots may not be used to circumvent thresholds established in legislation to determine when competitive tendering procedures must be used (European Union 2014)
}

EU reported whether SMEs participated and won tenders in 2016 and $2017 .^{4}$

We find that the quality of PP regulation, as measured by indicators compiled by the World Bank and by DigiWhist - a European public sector accountability research initiative ${ }^{5}$ - has a statistically significant positive relationship with SME participation in PP tenders. We also find an associated positive probability that an SME wins a PP contract. SMEs are more likely to submit bids when government entities employ open procedures (first price auctions) and when contracts are of small size. Threshold regression analysis reveals that conditional on contract size, dividing projects into smaller lots increases the probability that a SME wins the contract. To the best of our knowledge, these findings contribute to the literature on PP by being the first to document that measures aimed at facilitating SME participation in $\mathrm{PP}$ - as distinct from requiring preferential treatment of SMEs - can be effective.

The plan of the article is as follows. Section 1 discusses our research question and places it in the context of related literature. Section 2 characterizes the quality of PP regimes across countries, one of our explanatory variables. Section 3 describes the procurement data used. Section 4 reports the results of empirical analysis of the relationship between PP regulation and SME participation in procurement contests and the probability of success. Section 5 concludes.

\section{Public procurement regulation and SMEs}

Much of the extant empirical analysis of the effects of PP regulation tends to take a public sector governance perspective. Studies have shown that adoption of internationally accepted good practices in public procurement, such as transparency and use of design and award processes that reduce discretion and the scope for corruption, lowers project costs and/or increases quality by increasing competition for contracts. For example, Knack et al. (2019), using enterprise data for 88

\footnotetext{
${ }^{4}$ The 2014 reform to EU procurement legislation entered into force in 2016. Including data on SME participation in 2016 and 2017 may have been motivated by the reform. No data are reported on SME participation in PP tenders for years prior to 2016

${ }^{5}$ DigiWhist is an acronym for Digital Whistleblower, an EU-funded research project that includes an assessment of PP regulation and related processes for 34 countries and the European Commission. See http://digiwhist.eu/
} 
countries, find that firms are more likely to participate in public procurement markets in countries with more transparent procurement systems that rely more on open competition. Taș (2020), focusing on public procurement in the European Economic Area, finds that PP regulation that is more aligned with internationally accepted good practice standards significantly increases competition and lowers average contract prices for procuring agencies. ${ }^{6}$

Recent thinking in the economics literature frames the impact of policy on SMEs through the entrepreneurial ecosystem. In this framing, policies can have a leveraged or multiplicative impact on SMEs and ultimately economic performance (Stam and van de Ven 2019). PP regulation arguably is a salient dimension of the entrepreneurial ecosystem, an element of both the "quality of government" that helps to define the investment climate in which firms operate and a specific source of demand for SMEs. ${ }^{7}$ There is a substantial literature assessing the (potential) role of PP as a mechanism to support innovation (Edler and Georghiou 2007; Aschoff and Sofka 2009; Edler and Yeow 2016) and SME entrepreneurship (Dennis Jr 2011; Harland et al. 2019). One reason is that PP can represent a meaningful source of demand for firms, so that a government contract may encourage firms to invest more, expand employment, and increase productivity (Ferraz et al. 2015; Hoekman and Sanfilippo 2019). Success in promoting greater participation by SMEs in PP may help attain broader industrial development objectives (Geroski 1990; Acemoglu et al. 2018), including through spillovers within geographical clusters of economic activity (Porter 1990).

SMEs may confront greater difficulty in contesting public procurement markets than large companies (OECD 2018). Specific characteristics of SMEs may inhibit them from bidding for public contracts. SMEs may have limited capacity to incur the cost of lengthy payment delays, satisfy bid security, minimum turnover or experience requirements, or difficulties in obtaining loans for the

\footnotetext{
${ }^{6}$ See also Baldi et al. (2016); Kenny and Crisman (2016), and Coviello and Mariniello (2014)

${ }^{7}$ The Stam and van de Ven (2019) conceptualization of the entrepreneurial ecosystem stresses (potential) market demand as a factor but does not explicitly consider the role of government as a source of demand
}

working capital needed to execute a contract on a timely basis (Loader 2011, 2015; OECD 2018). Both financial and human resource capacity constraints are likely to be more severe for SMEs than for large firms, with implications for the capability to incur the (opportunity) costs of dealing with the administrative requirements associated with bidding for public contracts.

Evenett and Hoekman (2005) argue there are two important dimensions of procurement regulation. One relates to "leveling the playing field" by removing discrimination that impedes participation by some firms (often foreign). The other centers on transparency and related mechanisms that reduce discretion and the potential for corruption or collusion in the allocation of contracts. Competition and transparency are core elements of what is internationally recognized as good procurement practice, where the goal is value for money. Nondiscrimination may reduce the prospects that SMEs can successfully contest procurement opportunities as it will boost potential competition. Greater transparency and due process may be a positive or a negative for small firms. ${ }^{8} \mathrm{On}$ the one hand, it reduces fixed costs and there is a presumption that small firms will be less able to provide bribes or side-payments than larger firms. On the other hand, less discretionary procurement practices may encourage greater participation by firms that otherwise would refrain from bidding for contracts - or were simply excluded because they were not "connected." How public procurement regimes where contracts are allocated based on transparent and competitive processes will affect participation by domestic SMEs - our research question - is therefore an empirical question.

Governments tend to take two types of approaches to enhance the participation of SMEs in PP. The first comprises measures that aim at "leveling the playing field" for SMEs, through, e.g., calling for contracts to split into parts that may be easier for an SME to bid on and for contracts to be awarded based on the "most economically advantageous tender" rather than the lowest price. Both are elements of EU procurement practice. The second goes further and involves proactive measures in PP legislation that favor SMEs, through, e.g.,

\footnotetext{
${ }^{8}$ Flynn and Davies (2017) use a survey of 3000 firms that bid for contracts with Irish procuring entities and find that procedural capability is associated with frequency of tendering and the typical value of contract sought. In contrast, relational capability was not found to be a determining factor. Procedural and relational capabilities were both significant in accounting for success rates in procurement competitions
} 
set-aside requirements and price preferences. ${ }^{9}$ The extant literature assessing the effect of policies targeting SMEs is relatively limited and has tended to focus on the latter types of proactive policies. Nielsen (2017) surveys the existing research on the impact of SME-specific PP policies. He concludes there is some evidence that these result in greater SME engagement in procurement but also notes the evidence is mostly of a case study nature, with little attention given to the potential costs of SME preferences in terms of value for money forgone. Nakabayashi (2013) develops a theoretical framework to assess the effects of SME set-asides and procurement preferences and applies this to public procurement of construction services in Japan. He concludes that setaside programs increased SME participation in public procurement auctions by approximately $40 \% .^{10}$

In the present article, we cannot assess the effects of explicit PP preferences for SMEs because the EU- the source of our data on PP calls for tender and awards - does not apply such measures. In contrast to other jurisdictions, the EU does not use proactive discriminatory measures in its procurement legislation to favor SMEs in contract awards. Instead, the EU seeks to encourage participation by SMEs in public contracts by reducing barriers to entry and costs associated with PP processes (European Commission 2008). Specifically, reforms to EU PP legislation introduced in 2014 encouraged procuring entities to complement the use of a "most economically advantageous tender" criterion as opposed to the allocation of contracts to the lowest price bidder with the following elements: (i) reduce the average size of contracts where possible; (ii) consider subdivision of contracts into smaller lots where this is not detrimental to the realization of project objectives; (iii) implement e-procurement systems; and (iv) ensure timely payments (European Union 2014). ${ }^{11}$

\footnotetext{
${ }^{9}$ Measures to support SME participation in PP overlap with policies that aim to assist minority-owned firms. Public procurement preferences are important policy tools in some countries as an instrument to support minority-owned entrepreneurship. This dimension of public procurement regulation has attracted substantial attention in the literature (e.g., Fairlie and Marion 2012; Shelton and Minniti 2018). As noted by Bates et al. (2018) in their introduction to the March 2018 special issue of Small Business Economics, minority entrepreneurship has been the focus of much scholarly research. In this article, our focus is on SMEs as such, not on issues relating to specific types of SMEs or certain groups in society

${ }^{10}$ See also Marion $(2007,2011)$

${ }^{11}$ Trybus and Andrecka (2017) discuss the SME-oriented changes in the 2014 EU procurement directive. Israel, Japan, South Korea, New Zealand, Egypt, and Albania have similar provisions in their national procurement regulation (Nielsen 2017; OECD 2018)
}

Our focus is on the role of national procurement regimes in general and on the four types of measures implemented in the 2014 EU procurement regulation, including dividing contracts into smaller lots to make them more accessible to SMEs. Research on the effectiveness of the "EU approach" has cast doubt on the efficacy of some its elements. Stake (2017), using Swedish PP contract award data, concludes that the use of "most economically advantageous" criteria in tender awards rather than lowest price did not increase SME participation and success rates. A reason for this may be the finding by Ancarani et al. (2019) based on a survey of SMEs in Canada, Hungary, and Italy that administrative requirements or price competitiveness is not regarded as a major barrier to participation in procurement auctions. Instead, limited human resource capacity and financial strength were reported as more important impediments. These factors commonly are found to be participation constraints in the literature. Direct targeting of these factors, including ensuring timely payment for services, should therefore facilitate greater participation in PP tenders by SMEs.

The same applies to splitting contracts into smaller lots. Evidence of the effects of this is both limited and mixed. Timmermans and Zabala-Iturriagagoitia (2013) argue that "coordinated unbundling" of contracts can be effective in promoting participation of SMEs in public procurement, but Glas and Eßig (2018), using data on 380 contract awards in Germany to assess the effectiveness of splitting tenders into lots, find that this does not significantly increase the success rate of SMEs. Instead, they argue that other factors, including the type of public procurement procedure, the degree of competition (number of participating companies), and the overall tender volume, influence SME success. Blind et al. (2020) suggest that one such factor may be the extent to which firms are successful in offering innovative solutions and engage in standardization activities at standards development organizations.

\section{Characterizing public procurement regulation}

The basic features of good administrative practice in public procurement from a value for money perspective are well known. ${ }^{12}$ They include requiring procuring authorities to conduct procurement in a transparent and

\footnotetext{
${ }^{12}$ See, e.g., UNCITRAL (2014) and World Bank (2017)
} 
impartial manner and utilizing open (competitive) tendering methods to award contracts above a minimum value threshold. ${ }^{13}$ Notices of intended or planned procurement should be published (including information on timeframe, treatment of tenders and contract awards, technical requirements, and evaluation criteria used to determine the winning bid and payment terms). Implementing regulations should specify whether procuring entities may (or must) treat domestic bids more favorably than those from foreign companies or consortia, what such treatment comprises and the criteria that apply. ${ }^{14}$ Transparency is important for firms to be aware of opportunities. Publication of notices, ensuring sufficient time to prepare bids, and clearly specifying performance requirements are particularly important to SMEs as small firms have less capacity to be informed about procurement opportunities.

Djankov et al. (2017) characterize the quality of PP regulation for 142 countries in 2016. They assess three dimensions of the procurement process: (i) bid preparation; (ii) the content and management of the procedures used to award contracts; and (iii) payment of suppliers. The bid preparation score gauges the quality of the needs assessment associated with procurement projects and the call for tenders. The bid and contract management score considers the processes used for submission and evaluation of bids. The payment of suppliers' score measures payment timeframes and the procedures for request of payment. The arithmetic mean of these scores is used to calculate an overall public procurement score. The data used to construct these scores come from surveys of more than 1900 PP experts. Djankov et al. (2017) describe the questionnaire and the coding of the scores in detail.

An alternative exercise with a similar goal but less comprehensive country coverage is the DigiWhist initiative, a EU Horizon 2020 research project involving a consortium of six European research institutes. It covers the (then) $28 \mathrm{EU}$

\footnotetext{
${ }^{13}$ Open tendering is any method that allows any supplier to bid, including international firms (also called international competitive bidding). Selective tendering is a method where only suppliers that satisfy specific criteria for participation may bid (usually prequalified suppliers). Limited tendering is noncompetitive and usually involves a procuring entity approaching one or more potential suppliers of its choice

${ }^{14}$ See, e.g., http://www.sigmaweb.org/publications/key-publicprocurement-publications.htm, for a set of policy briefs summarizing the EU procurement rules and guidance as well as general good procurement practice
}

member states, the European Commission, Armenia, Georgia, Iceland, Norway, Serbia, and Switzerland. One element of the project is to produce data measuring the transparency of public administration and the accountability of public officials based on both de jure and de facto practices pertaining to the scope, information availability, evaluation, open competition, and institutional aspects of public procurement in European countries. The DigiWhist effort builds on indicators used in the World Bank Public Accountability Mechanisms (PAM) initiative. The resulting EuroPAM indicators score the quality of PP processes and regulation in the European countries considered. DigiWhist public procurement quality scores are available from 2012 to 2017. Accordingly, we consider the annual changes in procurement quality when we employ DigiWhist quality scores in the empirical analysis.

Table 1 reports summary statistics for PP quality indicators generated by the two sources for European countries for which we have data on participation by SMEs and outcomes (awards) from the EU Tenders Electronic Daily (TED) database. These data are discussed further in Section 4 below. The summary statistics for the two sources of policy information are comparable.

Figure 1 displays the overall PP quality scores for European countries. It reveals there is some variation across the two sources in scores and associated rankings of the European countries included in the sample. ${ }^{15}$ The overall PP indices vary significantly across countries, making it possible to assess how PP regulation quality affects levels of competition and costeffectiveness using data on the outcomes of procurement processes from the TED database. In the empirical analysis, we consider the association between the basic features of PP regulation and participation by SMEs, complemented with a focus on a specific measure that has been adopted by the EU to encourage SME engagement: dividing contracts into smaller lots. Our interest is to analyze empirically the "EU approach" which centers on implementation of what are agreed — both at EU level

\footnotetext{
${ }^{15}$ The graph reports average of scores for 2016 and 2017 for each county averages mask variation in the composite index components. For example, Slovakia has the highest bid preparation score of 0.9, while Iceland and Portugal have the lowest scores on this component (0.58). Similarly, bid and contract management and payment of suppliers' scores differ substantially across countries
} 
Table 1 World Bank and DigiWhist public procurement indicators, in selected European states

\begin{tabular}{llll}
\hline & Mean & Standard dev. & Min \\
\hline PP overall index & 0.73 & 0.09 & 0.58 \\
EuroPAM country score (year 2016) & 0.62 & 0.01 & 0.45 \\
EuroPAM country score (year 2017) & 0.63 & 0.11 & 0.45 \\
\hline
\end{tabular}

The World Bank Benchmarking Public Procurement (BPP) overall indicator ranges from 0 to 1, with higher scores denoting better quality regulation. EuroPam scores range between 0 and 100. The World Bank data span 31 European countries; DigiWhist covers one additional European country (Malta). EuroPam scores are divided by 100 to be on the same scale as BPP

and internationally - to be good general procurement practices, including measures introduced in the 2014 EU PP reforms that sought to "level the playing field" for SMEs, without explicitly favoring them. ${ }^{16}$

\section{Methodology}

\subsection{Data and sample}

We use the World Bank and DigiWhist information on the quality of PP regulation and PP contract award data for 32 European countries sourced from the TED database, which contains information on all tender opportunities as well as information on contract awards made by procuring entities in the European Economic Area (EU28, Iceland, Lichtenstein, and Norway), Switzerland, and the former Yugoslav Republic of Macedonia. ${ }^{17}$ In addition to acting as a platform for calls for tenders, TED is also a depository of information on PP outcomes, i.e., which firms win contracts.

Data in TED pertain to the three main categories of PP distinguished in EU law-services, supplies (goods), and works (construction- and infrastructure-related projects). Data are reported on the number and value of contracts issued by procuring entities for each of these three categories, as well as the procurement procedure that applies. These include open (competitive) bidding, restricted procedures, and the so-called competitive dialog. The first two account for most procurement. Under

\footnotetext{
${ }^{16}$ The World Bank and DigiWhist characterizations of the quality of PP regulation do not include measures capturing whether policy seeks to earmark or provide explicit preferences to SMEs, precluding an empirical analysis that contrasts the EU approach with those of countries with proactive policies that favor SMEs

${ }^{17}$ The World Bank and DigiWhist do not calculate PP quality scores for Liechtenstein. As a result, instead of 33 countries available in the TED dataset, we examine 32 European countries
}

open procedures, contracting authorities are required to publish procurement opportunities in the Official Journal of the EU, specify the technical criteria that bidders must satisfy, and evaluate bids and allocate contracts on the basis only of the bids received. Restricted procedures, used for higher-value contracts, involve a process where contracts are awarded based on competition between prequalified suppliers that express interest in participating. Some $85 \%$ of PP contracts are allocated through open procedures in the European Economic Area, accounting for about three-fifths of total PP by value (Kutlina-Dimitrova and Lakatos 2016). ${ }^{18}$

Public authorities are obliged to publish their tender invitations on TED for all contracts exceeding EU public procurement thresholds. For the period under analysis, the thresholds were $€ 135,000$ for public sector supply and service contracts issued by central government entities ( $€ 209,000$ for other authorities); $€ 387,000$ for utility supply and service contracts; $€ 80,000$ for small lots within a project above the services threshold; and $€ 5,225,000$ for construction/utility works and services concession contracts. Many contracts that fall below these thresholds are also reported in TED, as authorities often use TED to publicize tenders independent of contract values.

The TED data are available online in CSV format starting in 2006. ${ }^{19}$ The European Commission extracts the data from standard forms pertaining to the initial contract notice and final contract award notice that must be provided by each procuring authority. ${ }^{20}$ For each

\footnotetext{
${ }^{18}$ Negotiated procedures have the same transparency requirements as open and restricted tendering but permit the contracting entity to negotiate with potential bidders. The use of this procedure is circumscribed and in principle is limited to complex projects where there may be alternative technical solutions or a procuring authority is unable to determine ex ante how best to attain its objectives or needs

${ }^{19}$ We use the contact award notices csv files available at https://data. europa.eu/euodp/data/dataset/ted-csv

${ }^{20}$ These standard forms are available at http://simap.ted.europa. $\mathrm{eu} / \mathrm{web} /$ simap/standard-forms-for-public-procurement
} 
contract, the TED database includes fields for the estimated contract value (determined by the procuring entity), the actual contract (award) price, the sectoral Common Procurement Vocabulary (CPV) code that applies to the subject of procurement, ${ }^{21}$ the procurement method used, type(s) of contracting authority, and the names and locations of both the procuring agencies and the winning firms. TED includes information on SME participation for 2016 and 2017. A total of $1,018,794^{22}$ tenders were awarded in these 2 years. For 205,578 of these tenders, or $20 \%$ of the total, information is reported on the number of SMEs that participated in the tender process. We focus on this subsample of contracts in the empirical analysis. $^{23}$

\subsection{Dependent variable}

We start with the economic factors that affect participation of SMEs in PP, using the ratio of SME bidders to total bidders for a contract $c$ as the dependent variable, ${ }^{24}$ and then examine the probability that an SME wins a contract. Information on whether an SME wins a tender is available for a larger set of contracts $(531,164$ in total), but data often are not reported on the number of SMEs participating in the PP tender process. Of the 531,164 contracts where information is reported whether an SME is awarded the contract, the SME win ratio is $53 \%$. This ratio is higher in the subsample of 205,578 tenders for which we have information on the number of SME bidders per tender, i.e., participation rates are

\footnotetext{
${ }^{21}$ The CPV establishes a single classification system for public procurement aimed at standardizing the references used by contracting authorities and entities to describe the subject of procurement contracts. The economic sector that contracts are associated with is identified by the first two digits of the CPV code. The CPV distinguishes 45 major sectors. See https://simap.ted.europa.eu/web/simap/cpv

22459,393 in 2016 and 559,401 in 2017

${ }^{23}$ No information is reported on SME participation in the remaining 813,216 contracts in 2016 and 2017. TED does not report information on SME participation for the pre-2016 period, which may be explained by the fact that the 2014 reform entered into force in 2016. Appendix Table 16 provides descriptive statistics for our sample of 205,578 tenders for which SME participation rates are reported. The last two columns of Appendix Table 16 report the share of total contracts per TED sector for both the subsample for which TED reports information on the number of SME participants in a tender and for the total sample, i.e., all contracts, for 2016-2017. This reveals that the sectoral distribution of contracts for the subsample is very similar to that for all contracts, suggesting that the analysis of the set of contracts where information is reported on the number of SME participants is not affected by selection bias

${ }^{24}$ We use the standard OECD/EU definition of SMEs as this is the basis for the data reported in the TED database
}

reported. In this subsample, which we use for the empirical analysis, $67 \%$ of tenders are won by an SME. Most of these contracts $(185,682)$ were awarded using open procedures (first price auctions). ${ }^{25}$

\subsection{Independent variables}

We employ public procurement regulation quality scores described in Section 3 as the main independent variables. Additionally, we examine whether dividing contracts into smaller lots promotes SME participation. The TED data contains information about the number of lots for each contract. We construct an independent variable, dividedlots, if the contract has more than one lot. Almost $80 \%(163,265)$ of the contracts in our subsample involved division of a part of the project into smaller lots. ${ }^{26}$ Some $60 \%(123,842)$ of these tenders had estimated contract values exceeding the legal thresholds that determine if EU procurement regulations apply. Thus, $40 \%$ of the contracts in our sample are below the thresholds established in the EU regulation determining if PP rules must be implemented, i.e., publication of tenders and reporting information on winning bidders. This feature of the database is important for the empirical analysis as we are interested in low-value contracts that are more likely to be won by SMEs. The ratio of below threshold to total contracts is somewhat higher to that observed in the complete TED database, where $716,571(70.3 \%)$ of all contracts are above the value thresholds specified in EU PP regulation.

\subsection{Control variables}

We use several control variables, including dummy variables for the type of procurement method used, the type of public procurement authority that issued the call for tenders, whether estimated costs exceed the legal thresholds above which EU procurement law applies, and whether the contract is divided into smaller lots. Sector fixed effects are used to control for possible

\footnotetext{
${ }^{25}$ This ratio is comparable to what is observed in the complete TED dataset of $1,018,794$ contracts, where $899,428(88.4 \%)$ use the open procedure. Only 3934 of these tenders reported the use of electronic procurement mechanisms. The low share of e-procurement may reflect slow take-up of such mechanisms in Europe. EU procurement regulation requiring that all communication and information with bidders, including tender submissions, be performed using electronic means only came into effect on 18 October 2018

${ }^{26}$ This compares to $785,671(77.1 \%)$ of all contracts in full sample of TED contracts for 2016-2017 that are subdivided into smaller lots
} 
Fig. 1 Public procurement regulation scores for EU countries
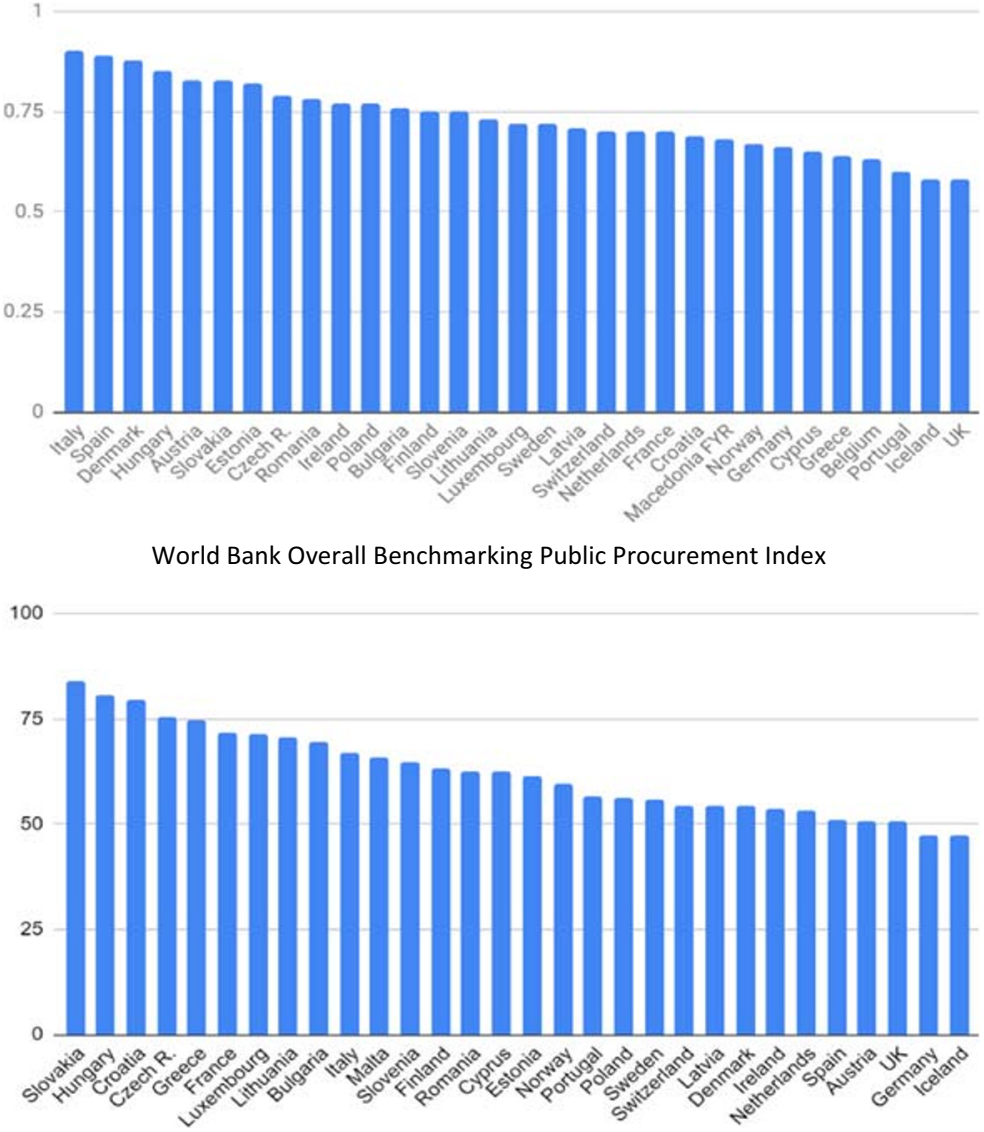

Average DigiWhist EuroPam country scores sector-specific dimensions of PP participation and outcomes. ${ }^{27}$ Contracts in the subsample are weighted towards goods: $79.3 \%$ of contracts comprise procurement in goods sectors (including works); services account for 20.7 of awarded contracts. Participation and win rates for SMEs competing for goods and services contracts are very similar. Table 2 reports summary statistics for the dependent and control variables.

The PP quality scores may be endogenous due to unobserved factors that affect both the total number of bidders, the number of SME bidders, and quality scores. In that case, the error term of the regression equation, $\varepsilon_{\mathrm{c}}$, will contain these unobserved factors, the quality scores

\footnotetext{
${ }^{27}$ Some types of PP contracts are likely to be less accessible to SMEs, e.g., tenders for products or services where economies of scale are large, making SMEs less competitive than large firms. In our sample, SME participation rates are similar across sectors. The main exceptions are PP tenders for water, petroleum products, public utilities, and financial services - sectors with substantial scale economies or regulation. See Appendix Table 16
}

will be correlated with the error term, and this endogeneity problem will distort the empirical results. We employ two alternative instrumental variable (IV)GMM methodologies to consider possible endogeneity of PP quality score variables. One is to use lagged GDP per capita as an IV. This is exogenous to PP processes and highly correlated with the quality of PP regulation insofar as richer countries tend to have better institutions as reflected in rule of law and public sector governance performance. Appendix Table 8 presents the first-stage regressions. These show that lagged GDP per capita

Table 2 Summary statistics of the variables

\begin{tabular}{lllll}
\hline & Mean & Standard dev. & Min & Max \\
\hline Ratio of SME bidders & 0.69 & 0.42 & 0 & 1 \\
SME winner dummy & 0.53 & 0.5 & 0 & 1 \\
Above threshold dummy & 0.60 & 0.49 & 0 & 1 \\
Divided lot dummy & 0.79 & 0.40 & 0 & 1 \\
\hline
\end{tabular}


is positively and significantly correlated with the BPP and DigiWhist scores. Given that countries with widely differing per capita GDP levels are similar in terms of the share of SMEs in the size distribution of firms, the use of this instrument should not introduce an additional source of potential bias.

The second approach to control for possible endogeneity is to construct valid IVs using the Lewbel (2012) heteroscedasticity-based (HB) identification strategy to identify structural parameters when valid IVs do not exist. Lewbel (2012) constructs valid IVs that are independent of the error term using the heteroscedasticity structure of the error term. Additionally, we apply the approach of Conley et al. (2012) to obtain inferences when IVs are "plausibly exogenous," i.e., when the correlation between the IVs and endogenous variables are near 0 but not exactly 0 , to examine the validity of the IV-GMM estimation by constructing linear models such that the IV validity condition is not satisfied. This methodology allows us to use "instruments that are strong but may violate the exclusion restriction" (Conley et al. 2012, p. 261).

\subsection{Estimation strategy}

Our empirical analysis addresses three questions: (1) the relationship between PP regulation and SME participation in tenders, (2) whether higher quality PP processes are associated with a higher probability of an SME winning a contract, and (3) whether dividing larger projects (contracts) into smaller lots increases SME participation and their probability of success. The first two questions use both the World Bank and DigiWhist PP policy scores as a measure of the quality of the administrative processes prevailing in each country. To the best of our knowledge, the third question has not been the subject of empirical analysis to date.

To examine the first research question, we estimate the following regression equation:

$$
\begin{aligned}
\text { Ratio }_{c}= & \beta_{1} P P Q_{c}^{i}+\beta_{2} P_{c}+\beta_{3} \text { above }_{c} \\
& +\beta_{4} \text { divided }_{c}+\sum_{z=1}^{9} \beta_{z+4} P A_{c}^{z} \\
& +\sum_{s=1}^{44} \beta_{s+13} \text { Sector }_{c}^{s}+\varepsilon_{c}
\end{aligned}
$$

where Ratio $_{c}$ is the ratio of bids by SMEs to the total number of bids submitted for each contract. $P P Q_{c}^{i}$ is the public procurement quality score $i$, where $i$ identifies whether the World Bank Overall Benchmarking Public
Procurement score or the DigiWhist EuroPAM country scores are used. ${ }^{28} P M_{c}$ is a dummy variable for the use of open procurement methods and $P A_{c}^{z}$ is a dummy variable denoting the type of public procurement authority that issued the call for tenders. Sector ${ }_{c}^{s}$ denotes 44 sector fixed effects. In addition, we use dummy variables for whether estimated costs exceed the legal thresholds above which EU procurement law applies, above $_{c},{ }^{29}$ and whether the contract is divided into smaller lots, divided $_{c}$. As noted above, we also use two different IV strategies to control for possible endogeneity. All estimations use robust standard errors.

For the analysis of the second research question, we employ two alternative regression specifications. First, we estimate the following logit equation:

$\operatorname{Prob}\left(S_{\text {SME_Winner }}=1 \mid \mathrm{x}\right)=F\left(x_{i t} \beta\right)$

where $S M E \_$Winner $_{c}$ is a dummy variable that equals 1 if an SME wins the public procurement contract and is 0 otherwise. $F\left(x_{i t}^{\prime} \beta\right)$ is a logit probability function of $x_{i t}^{\prime} \beta$, where $x_{i t}$ contains the explanatory variables discussed previously. Second, we gauge the impact of PP regulation quality $\left(P P Q_{c}^{i}\right)$ on the probability that an SME wins the contract. Given that quality scores may be endogenous, we again estimate a linear probability model using IV-GMM and lagged GDP per capita as an IV. Lewbel (2018) shows that a linear probability model can be estimated using heteroscedasticity-based (HB) instrumental variables in instances where the dependent variable is binary and an explanatory variable is potentially endogenous. Accordingly, we correct for possible endogeneity of the $P P Q_{c}^{i}$ variables by implementing the IV-GMM methodology of Lewbel (2012) to the following linear probability model which uses the same controls as in Eq. (1):

$$
\begin{aligned}
\text { SME_Winner }_{c}= & \beta_{1} P P Q_{c}^{i}+\beta_{2} P M_{c}+\beta_{3} \text { above }_{c} \\
& +\beta_{4} \text { divided }_{c}+\sum_{z=1}^{9} \beta_{z+4} P A_{c}^{z} \\
& +\sum_{s=1}^{44} \beta_{s+13} \text { Sector }_{c}^{s}+\varepsilon_{c}
\end{aligned}
$$

\footnotetext{
${ }^{28}$ World Bank (2017) do not have public procurement regulation scores for Liechtenstein and Malta. The TED dataset contains only 311 contracts for Liechtenstein and 2518 for Malta

${ }^{29}$ For the period under analysis, the main thresholds were $€ 135,000$ for public sector supply and service contracts issued by central government entities ( $€ 209,000$ for other authorities); $€ 387,000$ for utility supply and service contracts; $€ 80,000$ for small lots within a project above the services threshold; $€ 5,225,000$ for public sector and utility works and services concession contracts
} 
Finally, we implement the following threshold regression specification to investigate the third research question:

$$
\begin{aligned}
\text { SME_Winner }_{c}= & \beta_{1} P P Q_{c}^{i}+\beta_{2} P M_{c}+\beta_{3} \text { above }_{c} \\
& ++\sum_{j=0}^{m} 1_{j}\left(\text { lotsize }_{j}, \gamma\right){\text { dividedlots } \beta_{d l}} \\
& ++\sum_{z=1}^{9} \beta_{z+4} P A_{c}^{z} \\
& +\sum_{s=1}^{44} \beta_{s+13} \text { Sector }_{c}^{s}+\varepsilon_{c}
\end{aligned}
$$

where $1_{j}\left(\right.$ lotsize $\left._{j}, \gamma\right)$ takes the value 1 if the expression that $\gamma_{j} \leq$ lotsize $_{j} \leq \gamma_{j+1}$ is true. Therefore, the coefficient of the dividedlots variable, $\beta_{d l}$, can differ across values of the threshold variable, lot size.

\section{Empirical analysis and findings}

\subsection{SME participation}

Estimation results indicate that countries with better public procurement quality scores attract significantly more SME bidders and achieve higher levels of competition (Table 3). Good procurement practices do not favor large firms disproportionately - to the contrary. The same holds for the use of open procedures to award contracts. The coefficient estimate for the dummy variable for the use of "open procedures" is statistically significant and positive in sign, implying that the ratio of SME to total bidders is higher when authorities use open (competitive) PP procedures. As expected, larger contracts are associated with lower participation of SMEs: contracts that are above the legal thresholds established in EU law are less likely to induce participation by SMEs. ${ }^{30}$

\subsection{Probability that an SME wins a contract}

In this subsection, we examine only the contracts where an SME submitted a bid and investigate whether public procurement regulation quality affects the probability that an SME wins a contract. ${ }^{31}$ Table 4 reports the

\footnotetext{
$\overline{{ }^{30} \text { These results }}$ are not driven by the inclusion of below threshold contracts in our sample. If the regressions are run using only data on contracts that exceed the EU legal thresholds, the results are similar (Appendix Table 9)

31 As has been theorized and confirmed in the empirical analysis of PP markets, entry by SMEs in procurement contests is strongly associated

\begin{tabular}{|c|c|c|c|}
\hline & OLS & IV-GMM & HB-IV GMM \\
\hline & \multicolumn{3}{|c|}{ World Bank BPP measure } \\
\hline \multirow[t]{2}{*}{ World Bank PP score } & 0.16 & 0.21 & 0.11 \\
\hline & $(10.07)^{* *}$ & $(5.74)^{* *}$ & $(5.03)^{* *}$ \\
\hline \multirow[t]{2}{*}{ Open procedure } & 0.07 & 0.07 & 0.07 \\
\hline & $(19.63)^{* *}$ & $(19.46)^{* *}$ & $(19.72)^{* *}$ \\
\hline \multirow[t]{2}{*}{ Above threshold } & -0.03 & -0.03 & -0.03 \\
\hline & $(16.76)^{* *}$ & $(15.60)^{* *}$ & $(17.03)^{* *}$ \\
\hline \multirow[t]{2}{*}{ Divided lots } & 0.02 & 0.02 & 0.02 \\
\hline & $(7.07)^{* *}$ & $(7.20)^{* *}$ & $(6.98)^{* *}$ \\
\hline \multirow[t]{2}{*}{ Constant } & 0.57 & 0.53 & 0.60 \\
\hline & $(30.67)^{* *}$ & $(17.45)^{* *}$ & $(27.45)^{* *}$ \\
\hline$R^{2}$ & 0.08 & 0.08 & 0.08 \\
\hline \multirow[t]{2}{*}{ Observations } & 205,469 & 205,469 & 205,469 \\
\hline & \multicolumn{3}{|c|}{$\begin{array}{l}\text { DigiWhist EuroPAM Public Procuremen } \\
\text { Score }\end{array}$} \\
\hline \multirow[t]{2}{*}{ Country score } & 0.08 & 0.12 & 0.07 \\
\hline & $(8.67)^{* *}$ & $(5.73)^{* *}$ & $(4.83)^{* *}$ \\
\hline \multirow[t]{2}{*}{ Open procedure } & 0.067 & 0.067 & 0.067 \\
\hline & $(19.93)^{* *}$ & $(19.88)^{* *}$ & $(19.98)^{* *}$ \\
\hline \multirow[t]{2}{*}{ Above threshold } & -0.036 & -0.036 & -0.036 \\
\hline & $(18.41)^{* *}$ & $(18.41)^{* *}$ & $(18.40)^{* *}$ \\
\hline \multirow[t]{2}{*}{ Divided lots } & 0.017 & 0.017 & 0.017 \\
\hline & $(6.62)^{* *}$ & $(6.55)^{* *}$ & $(6.60)^{* *}$ \\
\hline \multirow[t]{2}{*}{ Constant } & 0.629 & 0.61 & 0.634 \\
\hline & $(39.93)^{* *}$ & $(32.17)^{* *}$ & $(37.18)^{* *}$ \\
\hline$R^{2}$ & 0.08 & 0.08 & 0.08 \\
\hline Observations & 205,465 & 205,465 & 205,465 \\
\hline
\end{tabular}
with win rates, i.e., SMEs participate in auctions they are more likely to win (Krasnokutskaya and Seim 2011; Li and Zheng 2009)
}

Table 3 Public procurement regulation and SME participation

Dependent variable: ratio of SME bidders to total number of bidders

${ }^{*} p<0.05 ; * * p<0.01$. Robust z-statistics in parentheses. IV-GMM employs lagged per capita GDP as an instrumental variable for the World Bank overall PP score and DigiWhist country score. All models include authority, sector, and year fixed effects. EuroPam scores are divided by 100 to be on the same scale as the World Bank BPP indicators

results of estimating Eqs. 2 and 3 using logit, IV, and HB-IV GMM regression specifications (the second row of Appendix Table 10 presents the Conley et al. (2012) estimation results). The coefficient estimates for the PP regulation quality scores are statistically significant and positive, suggesting that the likelihood that a SME will win a public procurement contract is higher when a country has better public procurement regulation quality. As is the case with the participation analysis in the previous subsection, above threshold contracts are 
Table 4 Procurement regulation quality and probability of SMEs winning a contract

\begin{tabular}{|c|c|c|c|c|}
\hline & \multirow[b]{2}{*}{ Logit } & \multicolumn{3}{|c|}{ Linear probability model } \\
\hline & & OLS & IV-GMM & $\begin{array}{l}\text { HB-IV } \\
\text { GMM }\end{array}$ \\
\hline & \multicolumn{4}{|c|}{ World Bank BPP measure } \\
\hline \multirow{2}{*}{$\begin{array}{l}\text { World Bank } \\
\text { PP score }\end{array}$} & 3.47 & 0.40 & 0.61 & 0.20 \\
\hline & $(22.31)^{* *}$ & $(22.77)^{* *}$ & $(24.19)^{* *}$ & $(7.90)^{* *}$ \\
\hline \multirow[t]{2}{*}{ Open procedure } & -0.15 & -0.02 & -0.02 & -0.01 \\
\hline & $(4.91)^{* *}$ & $(5.09)^{* *}$ & $(6.15)^{* *}$ & $(4.63)^{* *}$ \\
\hline \multirow[t]{2}{*}{ Above threshold } & -0.13 & -0.02 & -0.01 & -0.02 \\
\hline & $(8.03)^{* *}$ & $(8.58)^{* *}$ & $(4.76)^{* *}$ & $(10.54)^{* *}$ \\
\hline \multirow[t]{2}{*}{ Divided lots } & -0.13 & -0.02 & -0.01 & -0.02 \\
\hline & $(6.04)^{* *}$ & $(6.26)^{* *}$ & $(5.73)^{* *}$ & $(6.65)^{* *}$ \\
\hline \multirow[t]{2}{*}{ Constant } & -0.29 & 0.61 & 0.47 & 0.75 \\
\hline & $(1.78)$ & $(32.62)^{* *}$ & $(20.27)^{* *}$ & $(32.69)^{* *}$ \\
\hline$R^{2}$ & 0.03 & 0.03 & 0.02 & 0.03 \\
\hline \multirow[t]{2}{*}{ Observations } & 159,035 & 159,035 & 159,035 & 159,035 \\
\hline & \multicolumn{4}{|c|}{ EuroPAM Public Procurement Score } \\
\hline \multirow[t]{2}{*}{ Country score } & 1.23 & 0.13 & 0.33 & 0.14 \\
\hline & $(13.01)^{* *}$ & $(13.62)^{* *}$ & $(22.23)^{* *}$ & $(9.01)^{* *}$ \\
\hline \multirow[t]{2}{*}{ Open procedure } & -0.12 & -0.014 & -0.016 & -0.014 \\
\hline & $(4.12)^{* *}$ & $(4.36)^{* *}$ & $(5.21)^{* *}$ & $(4.36)^{* *}$ \\
\hline \multirow[t]{2}{*}{ Above threshold } & -0.20 & -0.023 & -0.019 & -0.023 \\
\hline & $(12.47)^{* *}$ & $(12.80)^{* *}$ & $(10.91)^{* *}$ & $(12.80)^{* *}$ \\
\hline \multirow[t]{2}{*}{ Divided lots } & -0.16 & -0.018 & -0.018 & -0.018 \\
\hline & $(7.15)^{* *}$ & $(7.29)^{* *}$ & $(7.58) * *$ & $(7.30)^{* *}$ \\
\hline \multirow[t]{2}{*}{ Constant } & 1.44 & 0.819 & 0.712 & 0.816 \\
\hline & $(10.48)^{* *}$ & $(54.02)^{* *}$ & $(42.82)^{* *}$ & $(49.23)^{* *}$ \\
\hline$R^{2}$ & 0.03 & 0.02 & 0.02 & 0.02 \\
\hline Observations & 159,039 & 159,039 & 159,039 & 159,039 \\
\hline
\end{tabular}

$* p<0.05 ; * * p<0.01$. Robust z-statistics in parentheses. IV for the World Bank overall PP score and the DigiWhist country score. All models include authority, sector, and year fixed effects. EuroPam scores are divided by 100 to be on the same scale as BPP

associated with a lower likelihood that SMEs win contracts. ${ }^{32}$ Noteworthy, however, is that the coefficient estimates for the use of open procedures and subdivision of lots are negative and statistically significant. These results suggest that good procurement practice encourages more SME participation that is rewarded with more contracts being awarded to SMEs (the result found in

\footnotetext{
32 If the regressions are run using only data on contracts that exceed the EU legal thresholds, the results are very similar (Appendix Table 11)
}

the previous section). But they also reveal that specific measures to ensure competition (use of open procedures) and increase the scope for SMEs to win contracts (subdivision of lots) may not do so.

That large firms are more likely to benefit from open procedures (open competition) is not surprising. That SMEs do not tend to benefit from decisions to subdivide lots is more surprising. In the next subsection, we conduct threshold regression analysis to examine the impact of lot size on the probability that SMEs win contracts. Specifically, we hypothesize that dividing contracts into smaller lots increases the chances of an SME winning only when the lots are small enough.

5.3 Multiple lot procurement and lot size: threshold regression analysis

The threshold regression identifies the critical lot size threshold for small contracts as $€ 23,469$ (Table 5). When lot size is smaller than this, the coefficient estimate on the dividedlots variable is positive and statistically significant. Dividing procurements into smaller lots increases the probability that an SME wins the contract. For lots with larger contract values, SMEs are less competitive and less likely to win public procurement contests even if contracts are subdivided. The threshold contract value is very small in absolute magnitude raising an empirical (and practical) question how many such contracts are observed in a country in a given year. In the case of the sample used for the analysis, $40 \%(81,736)$ of contracts had a value below the estimated threshold, suggesting some scope for this policy to enhance SME participation.

\section{Robustness checks}

\subsection{E-procurement}

A total of 3927 contracts report use of electronic procurement mechanisms. As mentioned above, the low share of e-procurement may reflect slow implementation by EU member states of e-procurement-related legislation, but as e-procurement is generally regarded as a way to reduce participation costs for smaller firms, we report the results of estimating Eqs. 1, 2, and 3 including a dummy variable for using e-procurement in Appendix Tables 12 and 13 (for the whole sample and for tenders in which at least one SME participated, respectively). Perhaps counterintuitively the results suggest that e-procurement is associated with 
Table 5 Lot size and probability of SMEs winning a contract

Lot size $<$ Euro 23,468.55 $(N=91,907)$

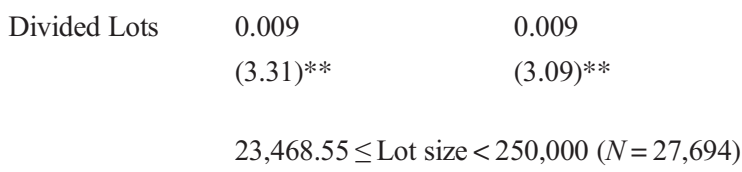

Divided lots $\quad-0.03 \quad-0.03$

$(9.39)^{* *} \quad(10.22)^{* *}$

Lot size $\geq 250,000(N=21,119)$

$\begin{array}{lll}\text { Divided lots } & -0.13 & -0.14 \\ & (26.26)^{* *} & (28.62)^{* *} \\ \text { WB PP score } & 0.32 & \\ & (20.32)^{* *} & \\ \text { Country score } & & 0.001 \\ & & (8.19)^{* *} \\ \text { Open procedure } & -0.019 & -0.017 \\ & (5.42)^{* *} & (4.89)^{* *} \\ \text { Above threshold } & -0.008 & -0.013 \\ & (3.90)^{* *} & (6.67)^{* *} \\ \text { Authority FE } & \text { Yes } & \text { Yes } \\ \text { Sector FE } & \text { Yes } & \text { Yes } \\ \text { Year Fe } & \text { Yes } & \text { Yes }\end{array}$

Threshold regression of linear probability model. Only tenders in which an SME submitted a bid are examined, i.e., number of SME offers $>0$. ${ }^{*} p<0.05$; ** $p<0.01$. First cloumn results use the World Bank BPP indicators; second column results use DigiWhist PP scores

less participation by SMEs in the set of contracts for which we have data. This finding calls for additional analysis.

\subsection{Timeliness of payments}

Timely payment of suppliers is important for SMEs as payment delays by a procuring entity will have a negative impact on cash flows of the firms executing a contract and their ability to cover running costs and pay financial liabilities. Djankov et al. (2017) construct an indicator to examine several aspects related to payment of suppliers including how burdensome the procedures are to request payments, the average time taken for processing of invoices and disbursement of payments by agencies, and the procedures that apply in instances where payments are delayed. We use this indicator (the payment score) to assess its salience for both SME
Table 6 Payment of suppliers' quality score and SME participation

\begin{tabular}{|c|c|c|c|}
\hline & OLS & IV-GMM & HB-IV GMM \\
\hline & \multicolumn{3}{|c|}{ World Bank BPP measure } \\
\hline \multirow[t]{2}{*}{ Payment quality score } & 0.05 & 0.45 & 0.03 \\
\hline & $(4.94) * *$ & $(5.72)^{* *}$ & $(2.09)^{*}$ \\
\hline \multirow[t]{2}{*}{ Open procedure } & 0.07 & 0.07 & 0.07 \\
\hline & $(19.94) * *$ & $(19.03)^{* *}$ & $(19.97)^{* *}$ \\
\hline \multirow[t]{2}{*}{ Above threshold } & -0.03 & -0.02 & -0.04 \\
\hline & $(17.56)^{* *}$ & $(8.29)^{* *}$ & $(17.80)^{* *}$ \\
\hline \multirow[t]{2}{*}{ Divided lots } & 0.02 & 0.03 & 0.02 \\
\hline & $(7.09)^{* *}$ & $(8.66)^{* *}$ & $(6.92)^{* *}$ \\
\hline Observations & 205,469 & 205,469 & 205,469 \\
\hline Authority FE & Yes & Yes & Yes \\
\hline Sector FE & Yes & Yes & Yes \\
\hline Year FE & Yes & Yes & Yes \\
\hline
\end{tabular}

$* p<0.05 ; * * p<0.01$. Robust z-statistics in parentheses. IV-GMM employs lagged GDP per capita as an instrumental variable

participation and the probability of SMEs winning contracts using the same regression specifications as previously. ${ }^{33}$ Tables 6 and 7 report the results. Table 6 reveals that payment scores are positively associated with SME participation. Similarly, Table 7 indicates a positive and significant relationship between payment score and the probability that an SME wins a contract.

\subsection{Sample selection}

Our sample spans the years 2016 and 2017. In 2016, 31,145 contracts were awarded for which information is reported on SME participation, whereas this information is reported for 176,097 contracts awarded in 2017. This creates a potential source of sample selection bias. Results from conducting the empirical analysis using only data for contracts awarded in 2016 is reported in Appendix Tables 14 and 15. Estimates are very similar to the main results presented in Tables 3 and 4 that use the whole sample. As noted previously, the sectoral distribution of contracts in our subsample of contracts for which TED reports SME participation numbers is very similar to that observed in the full sample of contracts (see Appendix Table 16), suggesting our main results are robust to sample selection.

\footnotetext{
$\overline{33}$ This indicator ranges between 0.5 and 1 , with a mean of 0.69 and standard deviation of 0.14
} 
Table 7 Payment of suppliers' quality score and probability of SME winning a contract

\begin{tabular}{lllll}
\hline & \multicolumn{4}{l}{ Linear probability model } \\
\cline { 3 - 5 } & Logit & OLS & IV-GMM & $\begin{array}{l}\text { HB-IV } \\
\text { GMM }\end{array}$ \\
\hline Payment quality & 1.87 & 0.21 & 0.96 & 0.05 \\
& $(19.69)^{* *}$ & $(20.01)^{* *}$ & $(29.60)^{* *}$ & $(3.80)^{* *}$ \\
Open procedure & -0.13 & -0.01 & -0.02 & -0.01 \\
& $(4.25)^{* *}$ & $(4.40)^{* *}$ & $(5.41)^{* *}$ & $(4.22)^{* *}$ \\
Above threshold & -0.15 & -0.02 & 0.01 & -0.02 \\
& $(9.05)^{* *}$ & $(9.52)^{* *}$ & $(2.63)^{* *}$ & $(11.93)^{* *}$ \\
Divided lots & -0.11 & -0.01 & 0.00 & -0.02 \\
Observations & 159,039 & 159,039 & 159,039 & 159,039 \\
Authority FE & Yes & Yes & Yes & Yes \\
Sector FE & Yes & Yes & Yes & Yes \\
Year FE & Yes & Yes & Yes & Yes \\
\hline
\end{tabular}

$* p<0.05 ; * * p<0.01$. Robust z-statistics in parentheses. IV-GMM employs lagged GDP per capita as an instrumental variable

\section{Discussion and concluding remarks}

Public procurement constitutes a major source of economic activity. The processes used to define needs, design projects, and allocate contracts to maximize value for money are important. The basic elements of what is generally accepted as constituting good practice in this area of public administration are well established. They involve mechanisms to ensure transparency, limit discretion, and constrain rent-seeking and corrupt practices. Competition is a key feature of good public procurement regulation.

Many governments are concerned that open, competitive procurement mechanisms that award contracts to the lowest priced bidder satisfying project-specific technical criteria may bias participation in procurement contests away from smaller companies towards large firms. In this article, we use a large dataset of procurement contracts issued by European countries that includes information on whether SMEs participated in bidding and on their success in winning contracts. We find that good procurement practice is good for SMEs: countries with higher PP regulation quality scores are associated with a larger ratio of SME participation and higher probability that SMEs win contracts. Controlling for PP regulation quality, the use of open competitive tendering methods tends to benefit large firms more than SMEs, with larger contracts more likely to be awarded to large firms. This finding may help to explain why many governments are interested in adopting measures that help SMEs participate in public procurement.

Rather than enact measures to favor SMEs by giving them preferential treatment, e.g., earmarking a share of procurement for SMEs or giving them a price advantage when allocating contracts, the EU has implemented measures "to level the playing field," including encouraging subdivision of contracts into smaller lots. This article offers the first evidence on the potential effects of such a policy. We find that it is associated with greater participation by SMEs but not with an increase in the probability of SMEs winning contracts. Threshold regression analysis suggests the absolute value of lot sizes matters. If lots are small enough - below $€ 25,000$ - the likelihood that SMEs win procurement contracts increases.

Our results suggest that insofar as governments are interested in enhancing participation by SMEs in public procurement auctions without resorting to explicit preferences, they should focus on improving the quality of generally applicable PP regulation. The findings also suggest subdivision and more generally the size of lots will enhance participation but may not increase SME win rates unless contracts are small. The low value of the threshold suggests it is important to minimize the administrative costs associated with bidding, something that eprocurement in principle should do. One practical implication of our findings is that policymakers should monitor and assess whether e-procurement systems do in fact reduce costs. As mentioned, we do not have enough observations on the use of e-procurement in our sample to assess its effect on SME participation.

Information on SME participation in TED is available only for the years 2016 and 2017. Continuing to collect and report this information will allow more robust assessments of the effects of procurement regimes and SME participation. It appears that this reporting exercise may have been a pilot or one-off initiative as such data are not reported for 2018. This is unfortunate as it impedes the ability to evaluate the impacts of PP policy and changes in regulation over time. Ultimately a key question from a policy perspective is not simply whether policies aimed at enhancing SME participation in PP tenders are effective, but whether this leads to sustained positive effects on the performance of SMEs - as reflected in productivity, innovation, and growth. Assessing the magnitude and persistence of effects requires information on the firms that participate in and win PP contests. Fadic (2020), for example, estimates the effects of government procurement participation on the growth of small firms in Ecuador, 
using a unique dataset based on administrative sources. That analysis finds that winning PP contracts has a positive and significant effect on firm growth but also that the effect is temporary, only observed during the year of the positive shock. Similar analysis for the EU requires matching TED data on the identity of winning firms with company-specific financial and operational information. Doing so would permit much greater insight in the efficacy of PP as a tool to promote SME performance.

Acknowledgments We are grateful to four reviewers, Ijaz Nabi, Moussa Saab, Marco Sanfilippo, and Anirudh Shingal, and participants in the 2020 annual conference of the Economic Research Forum for helpful comments on earlier versions. This article draws on work supported by the International Growth Centre under project no. LBN-19056.

Funding Open access funding provided by European University Institute - Fiesole within the CRUI-CARE Agreement.

\section{Appendix}

Table 8 First-stage regressions of IV-GMM

\begin{tabular}{lll}
\hline Dependent variable & Coefficient & $t$ statistic \\
\hline World Bank PP score & 0.032 & $415.27^{* * * *}$ \\
DigiWhist Country score & 5.73 & $520.46^{* * * *}$ \\
\hline
\end{tabular}

Table 10 Validity of instrumental variable plausibly exogenous instrumental variable (Conley et al. 2012)

\begin{tabular}{lll}
\hline Dependent variable & $\begin{array}{l}\text { Coefficient of } \\
\text { World Bank BPP } \\
\text { Measure }\end{array}$ & $\begin{array}{l}\text { Coefficient of } \\
\text { EuroPAM Public } \\
\text { Procurement Score }\end{array}$ \\
\hline $\begin{array}{c}\text { Ratio of SME } \\
\text { bidders (Table 2) } \\
\begin{array}{c}\text { Ratio of SME } \\
\text { winners (Table 3) }\end{array}\end{array}$ & $0.34 * *$ & $0.002 * *$ \\
\hline
\end{tabular}

$* p<0.05 ; * * p<0.01$. Robust $\mathrm{z}$-statistics in parentheses
Table 9 Public procurement regulation and SME participation (above threshold contracts)

\begin{tabular}{|c|c|c|c|}
\hline & OLS & IV-GMM & HB-IV GMM \\
\hline & \multicolumn{3}{|c|}{ World Bank BPP measure } \\
\hline \multirow[t]{2}{*}{ World Bank PP score } & 0.13 & 0.16 & 0.15 \\
\hline & $(7.18)^{* *}$ & $(5.45)^{* *}$ & $(5.71)^{* *}$ \\
\hline \multirow[t]{2}{*}{ Open procedure } & 0.06 & 0.06 & 0.06 \\
\hline & $(16.61)^{* *}$ & $(16.70)^{* *}$ & $(16.57)^{* *}$ \\
\hline \multirow[t]{2}{*}{ Divided lots } & 0.02 & 0.02 & 0.02 \\
\hline & $(6.56)^{* *}$ & $(6.81)^{* *}$ & $(6.60)^{* *}$ \\
\hline \multirow[t]{2}{*}{ Constant } & 0.53 & 0.51 & 0.52 \\
\hline & $(25.46)^{* *}$ & $(18.98)^{* *}$ & $(21.47)^{* *}$ \\
\hline Observations & 123,778 & 123,778 & 123,778 \\
\hline Authority FE & Yes & Yes & Yes \\
\hline Sector FE & Yes & Yes & Yes \\
\hline \multirow[t]{2}{*}{ Year FE } & Yes & Yes & Yes \\
\hline & \multicolumn{3}{|c|}{ DigiWhist EuroPAM Public Procurement Score } \\
\hline \multirow[t]{2}{*}{ Country score } & 0.001 & 0.001 & 0.001 \\
\hline & $(9.50)^{* *}$ & $(7.51)^{* *}$ & $(5.00)^{* *}$ \\
\hline \multirow[t]{2}{*}{ Open procedure } & 0.063 & 0.063 & 0.064 \\
\hline & $(16.62)^{* *}$ & $(16.62)^{* *}$ & $(16.70)^{* *}$ \\
\hline \multirow[t]{2}{*}{ Divided lots } & 0.018 & 0.016 & 0.018 \\
\hline & $(6.07)^{* *}$ & $(5.58)^{* *}$ & $(6.10)^{* *}$ \\
\hline \multirow[t]{2}{*}{ Constant } & 0.557 & 0.567 & 0.575 \\
\hline & $(30.85)^{* *}$ & $(31.20)^{* *}$ & $(30.04)^{* *}$ \\
\hline Observations & 123,781 & 123,781 & 123,781 \\
\hline Authority FE & Yes & Yes & Yes \\
\hline Sector FE & Yes & Yes & Yes \\
\hline Year Fe & Yes & Yes & Yes \\
\hline
\end{tabular}

Dependent variable: ratio of SME bidders to total number of bidders

${ }^{*} p<0.05 ; * * p<0.01$. Robust z-statistics in parentheses. IV-GMM employs lagged per capita GDP as an instrumental variable 
Table 11 Public procurement regulation and probability of SME winning a contract (above threshold contracts)

\begin{tabular}{|c|c|c|c|c|}
\hline & \multirow[b]{2}{*}{ Logit } & \multicolumn{3}{|c|}{ Linear probability model } \\
\hline & & OLS & IV-GMM & $\begin{array}{l}\text { HB-IV } \\
\text { GMM }\end{array}$ \\
\hline & \multicolumn{4}{|c|}{ World Bank BPP measure } \\
\hline $\begin{array}{l}\text { World Bank PP } \\
\text { score }\end{array}$ & $\begin{array}{l}2.91 \\
(16.78)^{* *}\end{array}$ & $\begin{array}{l}0.35 \\
(17.13)^{* *}\end{array}$ & $\begin{array}{l}0.76 \\
(24.71)^{* *}\end{array}$ & $\begin{array}{l}0.23 \\
(7.91)^{* *}\end{array}$ \\
\hline Open procedure & $\begin{array}{l}-0.16 \\
(4.72)^{* *}\end{array}$ & $\begin{array}{l}-0.02 \\
(4.77)^{* *}\end{array}$ & $\begin{array}{l}-0.02 \\
(6.23)^{* *}\end{array}$ & $\begin{array}{l}-0.02 \\
(4.51)^{* *}\end{array}$ \\
\hline Divided lots & $\begin{array}{l}-0.14 \\
(5.81)^{* *}\end{array}$ & $\begin{array}{l}-0.02 \\
(6.07)^{* *}\end{array}$ & $\begin{array}{l}-0.02 \\
(5.15)^{* *}\end{array}$ & $\begin{array}{l}-0.02 \\
(6.42)^{* *}\end{array}$ \\
\hline Constant & $\begin{array}{l}-0.16 \\
(0.88)\end{array}$ & $\begin{array}{l}0.62 \\
(28.53)^{* *}\end{array}$ & $\begin{array}{l}0.35 \\
(12.95)^{* *}\end{array}$ & $\begin{array}{l}0.70 \\
(26.99)^{* *}\end{array}$ \\
\hline Observations & 95,242 & 95,242 & 95,242 & 95,242 \\
\hline Authority FE & Yes & Yes & Yes & Yes \\
\hline Sector FE & Yes & Yes & Yes & Yes \\
\hline \multirow[t]{2}{*}{ Year Fe } & Yes & Yes & Yes & Yes \\
\hline & \multicolumn{4}{|c|}{ EuroPAM Public Procurement Score } \\
\hline Country score & $\begin{array}{l}0.02 \\
(15.81)^{* *}\end{array}$ & $\begin{array}{l}0.002 \\
(16.20)^{* *}\end{array}$ & $\begin{array}{l}0.005 \\
(23.92)^{* *}\end{array}$ & $\begin{array}{l}0.001 \\
(7.87)^{* *}\end{array}$ \\
\hline Open procedure & $\begin{array}{l}-0.15 \\
(4.44)^{* *}\end{array}$ & $\begin{array}{l}-0.017 \\
(4.56)^{* *}\end{array}$ & $\begin{array}{l}-0.022 \\
(5.86)^{* *}\end{array}$ & $\begin{array}{l}-0.016 \\
(4.39)^{* *}\end{array}$ \\
\hline Divided lots & $\begin{array}{l}-0.17 \\
(7.06)^{* *}\end{array}$ & $\begin{array}{l}-0.021 \\
(7.26)^{* *}\end{array}$ & $\begin{array}{l}-0.023 \\
(7.78)^{* *}\end{array}$ & $\begin{array}{l}-0.021 \\
(7.22)^{* *}\end{array}$ \\
\hline Constant & $\begin{array}{l}0.85 \\
(5.71)^{* *}\end{array}$ & $\begin{array}{l}0.746 \\
(42.41)^{* *}\end{array}$ & $\begin{array}{l}0.603 \\
(30.52)^{* *}\end{array}$ & $\begin{array}{l}0.781 \\
(41.49) * *\end{array}$ \\
\hline Observations & 95,247 & 95,247 & 95,247 & 95,247 \\
\hline Authority FE & Yes & Yes & Yes & Yes \\
\hline Sector FE & Yes & Yes & Yes & Yes \\
\hline Year Fe & Yes & Yes & Yes & Yes \\
\hline
\end{tabular}

$* p<0.05 ; * * p<0.01$. Robust Z-statistics in parentheses
Table 12 Effect of public procurement regulation quality on SME participation

\begin{tabular}{|c|c|c|c|}
\hline & OLS & IV-GMM & HB-IV GMM \\
\hline & \multicolumn{3}{|c|}{ World Bank BPP measure } \\
\hline \multirow[t]{2}{*}{ World Bank PP score } & 0.16 & 0.22 & 0.11 \\
\hline & $(10.41)^{* *}$ & $(5.96)^{* *}$ & $(5.03)^{* *}$ \\
\hline \multirow[t]{2}{*}{ Open procedure } & 0.07 & 0.07 & 0.07 \\
\hline & $(19.98) * *$ & $(19.81)^{* *}$ & $(19.72)^{* *}$ \\
\hline \multirow[t]{2}{*}{ Electronic procurement } & -0.05 & -0.05 & -0.03 \\
\hline & $(7.58)^{* *}$ & $(7.48)^{* * *}$ & $(17.03)^{* *}$ \\
\hline \multirow[t]{2}{*}{ Above threshold } & -0.03 & -0.03 & 0.02 \\
\hline & $(16.64)^{* *}$ & $(15.44)^{* *}$ & $(6.98)^{* * *}$ \\
\hline \multirow[t]{2}{*}{ Divided lots } & 0.02 & 0.02 & 0.11 \\
\hline & $(7.19)^{* *}$ & $(7.32)^{* *}$ & $(5.03)^{* *}$ \\
\hline Observations & 205,469 & 205,469 & 205,469 \\
\hline Authority FE & Yes & Yes & Yes \\
\hline Sector FE & Yes & Yes & Yes \\
\hline \multirow[t]{2}{*}{ Year FE } & Yes & Yes & Yes \\
\hline & \multicolumn{3}{|c|}{ EuroPAM Public Procurement Score } \\
\hline \multirow[t]{2}{*}{ Country score } & 0.001 & 0.001 & 0.0004 \\
\hline & $(9.16)^{* *}$ & $(5.96)^{* *}$ & $(2.19)^{*}$ \\
\hline \multirow[t]{2}{*}{ Open procedure } & 0.068 & 0.068 & 0.071 \\
\hline & $(20.27)^{* *}$ & $(20.24)^{* *}$ & $(20.96)^{* *}$ \\
\hline \multirow[t]{2}{*}{ Electronic procurement } & -0.048 & -0.049 & -0.046 \\
\hline & $(7.46)^{* *}$ & $(7.57)^{* *}$ & $(7.19)^{* *}$ \\
\hline \multirow[t]{2}{*}{ Above threshold } & -0.036 & -0.036 & -0.040 \\
\hline & $(18.33)^{* *}$ & $(18.33)^{* *}$ & $(19.48)^{* *}$ \\
\hline \multirow[t]{2}{*}{ Divided lots } & 0.017 & 0.017 & 0.016 \\
\hline & $(6.72)^{* *}$ & $(6.65)^{* *}$ & $(6.41)^{* *}$ \\
\hline Observations & 205,465 & 205,465 & 205,465 \\
\hline Authority FE & Yes & Yes & Yes \\
\hline Sector FE & Yes & Yes & Yes \\
\hline Year FE & Yes & Yes & Yes \\
\hline
\end{tabular}

Dependent variable: ratio $=$ number of SME bidders/total number of bidders

Regressions with electronic procurement explanatory variable ${ }^{*} p<0.05 ; * *<0.01$. Robust z-statistics in parentheses. IV-GMM employs lagged GDP per capita as an instrumental variable 
Table 13 Public procurement regulation quality and probability of SME winning a contract

\begin{tabular}{|c|c|c|c|c|}
\hline & \multirow[b]{2}{*}{ Logit } & \multicolumn{3}{|c|}{ Linear probability model } \\
\hline & & OLS & IV-GMM & $\begin{array}{l}\text { HB-IV } \\
\text { GMM }\end{array}$ \\
\hline & \multicolumn{4}{|c|}{ World Bank BPP measure } \\
\hline \multirow[t]{2}{*}{ World Bank PP } & 3.51 & 0.40 & 0.62 & 0.20 \\
\hline & $(22.61)^{* * *}$ & $(22.94) * *$ & $(24.30)^{* *}$ & $(7.77)^{* *}$ \\
\hline \multirow[t]{2}{*}{ Open procedure } & -0.14 & -0.01 & -0.02 & -0.01 \\
\hline & $(4.47)^{* *}$ & $(4.64) * *$ & $(5.74)^{* *}$ & $(4.17)^{* *}$ \\
\hline \multirow[t]{2}{*}{ E-procurement } & -0.52 & -0.06 & -0.06 & -0.06 \\
\hline & $(10.39)^{* *}$ & $(8.78)^{* *}$ & $(8.71)^{* *}$ & $(8.60)^{* *}$ \\
\hline \multirow[t]{2}{*}{ Above threshold } & -0.13 & -0.02 & -0.01 & -0.02 \\
\hline & $(7.93)^{* *}$ & $(8.43)^{* *}$ & $(4.63)^{* *}$ & $(10.47)^{* *}$ \\
\hline \multirow[t]{2}{*}{ Divided lots } & -0.13 & -0.01 & -0.01 & -0.02 \\
\hline & $(5.87)^{* *}$ & $(6.06)^{* *}$ & $(5.54)^{* *}$ & $(6.47)^{* *}$ \\
\hline Observations & 159,035 & 159,035 & 159,035 & 159,035 \\
\hline Authority FE & Yes & Yes & Yes & Yes \\
\hline Sector FE & Yes & Yes & Yes & Yes \\
\hline \multirow[t]{2}{*}{ Year FE } & Yes & Yes & Yes & Yes \\
\hline & \multicolumn{4}{|c|}{ EuroPAM Public Procurement Score } \\
\hline \multirow[t]{2}{*}{ Country score } & 0.013 & 0.001 & 0.003 & 0.001 \\
\hline & $(13.38)^{* *}$ & $(13.83)^{* *}$ & $(22.36)^{* *}$ & $(8.80)^{* *}$ \\
\hline \multirow[t]{2}{*}{ Open procedure } & -0.110 & -0.012 & -0.015 & -0.012 \\
\hline & $(3.68)^{* *}$ & $(3.91)^{* *}$ & $(4.79)^{* *}$ & $(3.91)^{* *}$ \\
\hline \multirow[t]{2}{*}{ E-procurement } & -0.504 & -0.062 & -0.063 & -0.062 \\
\hline & $(10.15)^{* *}$ & $(8.66)^{* *}$ & $(8.77)^{* *}$ & $(8.66)^{* *}$ \\
\hline \multirow[t]{2}{*}{ Above threshold } & -0.203 & -0.022 & -0.019 & -0.022 \\
\hline & $(12.43)^{* *}$ & $(12.68)^{* *}$ & $(10.80)^{* *}$ & $(12.68)^{* *}$ \\
\hline \multirow[t]{2}{*}{ Divided lots } & -0.155 & -0.017 & -0.018 & -0.017 \\
\hline & $(7.01)^{* *}$ & $(7.11)^{* *}$ & $(7.40)^{* * *}$ & $(7.10)^{* *}$ \\
\hline Observations & 159,039 & 159,039 & 159,039 & 159,039 \\
\hline Authority FE & Yes & Yes & Yes & Yes \\
\hline Sector FE & Yes & Yes & Yes & Yes \\
\hline Year FE & Yes & Yes & Yes & Yes \\
\hline
\end{tabular}

Only tenders that an SME has submitted a bid are examined. Number of SME offers $>0$

Regressions with electronic procurement explanatory variable $* p<0.05 ; * * p<0.01$. Robust z-statistics in parentheses. IV-GMM employs lagged GDP per capita as an instrumental variable 
Table 14 World Bank public procurement quality score and SME participation

Analysis with contracts in 2016 $* p<0.05$; ** $p<0.01$. Robust $\mathrm{z}-$ statistics in parentheses. IVGMM employs lagged GDP per capita as an instrumental variable
OLS IV-GMM

HB-IV GMM

World Bank BPP measure

\begin{tabular}{llll}
\hline & OLS & IV-GMM & HB-IV GMM \\
\hline \multirow{2}{*}{ World Bank PP score } & 0.11 & 0.64 & \\
& $(3.46)^{* *}$ & $(9.38)^{* *}$ & -0.20 \\
Open procedure & 0.09 & 0.08 & $(3.09)^{* *}$ \\
& $(11.38)^{* *}$ & $(10.30)^{* *}$ & 0.09 \\
Above threshold & -0.08 & -0.07 & $(11.20)^{* *}$ \\
& $(14.75)^{* *}$ & $(12.09)^{* *}$ & -0.09 \\
Divided lots & 0.01 & 0.01 & $(15.82)^{* *}$ \\
& $(2.28)^{*}$ & $(1.65)$ & 0.00 \\
Constant & 0.62 & 0.37 & $(0.20)$ \\
& $(19.69)^{* *}$ & $(6.40)^{* *}$ & 0.96 \\
Observations & 31,165 & 31,165 & $(17.22)^{* *}$ \\
Authority FE & Yes & Yes & 31,165 \\
Sector FE & Yes & Yes & Yes \\
\hline
\end{tabular}

Table 15 World Bank public procurement quality score and SME contract winning probability

Analysis with contracts in 2016 $* p<0.05$; ** $p<0.01$. Robust $\mathrm{z}-$ statistics in parentheses. IVGMM employs lagged GDP per capita as an instrumental variable

\begin{tabular}{lllll}
\hline & & \multicolumn{2}{l}{ Linear probability model } \\
\cline { 3 - 5 } & Logit & OLS & IV-GMM & HB-IV GMM \\
\hline World Bank PP & 1.49 & 0.20 & 0.45 & 0.16 \\
& $(4.82)^{* *}$ & $(5.13)^{* *}$ & $(8.36)^{* *}$ & $(2.41)^{*}$ \\
Open procedure & -0.22 & -0.03 & -0.03 & -0.03 \\
Above threshold & $(3.37)^{* *}$ & $(3.52)^{* *}$ & $(3.64)^{* *}$ & $(4.23)^{* *}$ \\
& -0.56 & -0.06 & -0.05 & -0.05 \\
Divided lots & $(11.59)^{* *}$ & $(12.28)^{* *}$ & $(10.62)^{* *}$ & $(9.07)^{* *}$ \\
Constant & -0.25 & -0.03 & -0.03 & -0.03 \\
Observations & $(5.01)^{* *}$ & $(5.09)^{* *}$ & $(4.93)^{* * *}$ & $(4.33)^{* *}$ \\
Authority FE & 1.70 & 0.83 & 0.64 & 0.93 \\
Sector FE & $(4.81)^{* *}$ & $(18.74)^{* *}$ & $(12.34)^{* *}$ & $(14.96)^{* *}$ \\
\hline & 22,775 & 22,775 & 22,775 & 22,775 \\
& Yes & Yes & Yes & Yes \\
& Yes & Yes & Yes & Yes \\
\hline
\end{tabular}


Table 16 Sectoral distribution of tenders, SME participation, and win ratio

\begin{tabular}{|c|c|c|c|c|c|c|c|c|}
\hline $\mathrm{CPV}$ & Sector & $\begin{array}{l}\text { Total } \\
\text { number of } \\
\text { contracts }\end{array}$ & $\begin{array}{l}\text { Average } \\
\text { number of } \\
\text { offers }\end{array}$ & $\begin{array}{l}\text { Average } \\
\text { number of } \\
\text { SME offers }\end{array}$ & $\begin{array}{l}\text { Total number } \\
\text { of contracts } \\
\text { won by SMEs }\end{array}$ & $\begin{array}{l}\text { SME } \\
\text { win ratio }\end{array}$ & $\begin{array}{l}\text { Percentage } \\
\text { of contracts } \\
\text { (with SME } \\
\text { information) }\end{array}$ & $\begin{array}{l}\text { Percentage of } \\
\text { contracts } \\
\text { (all contracts) }\end{array}$ \\
\hline 3 & Agriculture & 922 & 2.79 & 2.30 & 721 & 0.78 & 0.45 & 0.48 \\
\hline 9 & Petroleum products & 4601 & 3.03 & 1.15 & 1699 & 0.37 & 2.24 & 1.92 \\
\hline 14 & Mining & 492 & 6.77 & 5.94 & 395 & 0.80 & 0.24 & 0.22 \\
\hline 15 & Food & 31,521 & 2.67 & 1.96 & 22,887 & 0.73 & 15.33 & 5.51 \\
\hline 16 & Agricultural machinery & 348 & 2.39 & 2.10 & 290 & 0.83 & 0.17 & 0.13 \\
\hline 18 & Clothing & 1239 & 2.91 & 2.23 & 955 & 0.77 & 0.60 & 0.61 \\
\hline 19 & Leather and textile & 209 & 3.69 & 2.97 & 168 & 0.80 & 0.10 & 0.13 \\
\hline 22 & Printed matter & 1151 & 13.47 & 12.52 & 787 & 0.68 & 0.56 & 0.53 \\
\hline 24 & Chemical products & 1050 & 3.85 & 3.14 & 787 & 0.75 & 0.51 & 0.63 \\
\hline 30 & Office and computing machinery & 5714 & 5.45 & 4.59 & 4543 & 0.80 & 2.78 & 2.04 \\
\hline 31 & Electrical machinery & 1490 & 3.12 & 2.20 & 1009 & 0.68 & 0.72 & 0.77 \\
\hline 32 & Communication equipment & 1214 & 2.62 & 1.85 & 844 & 0.70 & 0.59 & 0.65 \\
\hline 33 & Medical equipment & 63,079 & 3.70 & 2.13 & 37,309 & 0.59 & 30.7 & 33.4 \\
\hline 34 & Transport equipment & 6586 & 2.95 & 1.99 & 4600 & 0.70 & 3.20 & 3.07 \\
\hline 35 & Security equipment & 876 & 2.18 & 1.68 & 671 & 0.77 & 0.43 & 0.50 \\
\hline 37 & $\begin{array}{l}\text { Musical instruments } \\
\text { and sports goods }\end{array}$ & 336 & 6.96 & 6.27 & 279 & 0.83 & 0.16 & 0.18 \\
\hline 38 & Laboratory equipment & 2761 & 4.86 & 2.87 & 2137 & 0.77 & 1.34 & 1.08 \\
\hline 39 & Furniture & 3437 & 4.16 & 3.33 & 2901 & 0.84 & 1.67 & 1.71 \\
\hline 41 & Water & 114 & 1.26 & 0.31 & 28 & 0.25 & 0.06 & 0.02 \\
\hline 42 & Industrial machinery & 1430 & 2.65 & 2.07 & 1133 & 0.79 & 0.70 & 0.75 \\
\hline 43 & Construction equipment & 631 & 4.39 & 3.35 & 492 & 0.78 & 0.31 & 0.34 \\
\hline 44 & Construction materials & 2691 & 3.11 & 2.26 & 1822 & 0.68 & 1.31 & 1.39 \\
\hline 45 & Construction work & 11,960 & 5.50 & 3.81 & 8618 & 0.72 & 5.82 & 8.48 \\
\hline 48 & Software & 1753 & 3.53 & 2.73 & 1252 & 0.71 & 0.85 & 0.78 \\
\hline 50 & Repair and maintenance & 5813 & 3.01 & 2.07 & 3980 & 0.68 & 2.83 & 3.31 \\
\hline 51 & Installation & 175 & 2.79 & 2.12 & 133 & 0.76 & 0.09 & 0.09 \\
\hline 55 & Hotel and restaurant & 1350 & 3.30 & 2.47 & 898 & 0.67 & 0.66 & 0.76 \\
\hline 60 & Transportation services & 5285 & 15.07 & 12.66 & 3820 & 0.72 & 2.57 & 3.08 \\
\hline 63 & Travel agency services & 421 & 7.70 & 5.80 & 297 & 0.71 & 0.20 & 0.23 \\
\hline 64 & Postal and telecommunication & 1449 & 2.00 & 0.86 & 562 & 0.39 & 0.70 & 0.71 \\
\hline 65 & Public utilities & 313 & 2.42 & 0.61 & 72 & 0.23 & 0.15 & 0.19 \\
\hline 66 & Financial and insurance & 2153 & 2.86 & 0.71 & 476 & 0.22 & 1.05 & 1.96 \\
\hline 70 & Real estate services & 390 & 14.62 & 6.17 & 270 & 0.69 & 0.19 & 0.22 \\
\hline 71 & Architectural and engineering & 8652 & 4.96 & 3.96 & 6835 & 0.79 & 4.21 & 4.83 \\
\hline 72 & IT services & 3089 & 3.37 & 1.92 & 1994 & 0.65 & 1.50 & 1.70 \\
\hline 73 & Research and development & 508 & 4.64 & 1.55 & 259 & 0.51 & 0.25 & 0.29 \\
\hline 75 & Administration & 453 & 3.75 & 2.71 & 325 & 0.72 & 0.22 & 0.26 \\
\hline 76 & Oil and gas & 55 & 2.87 & 1.69 & 30 & 0.55 & 0.03 & 0.05 \\
\hline 77 & Forestry & 8035 & 10.66 & 9.34 & 6874 & 0.86 & 3.91 & 2.49 \\
\hline 79 & Business services & 6083 & 6.36 & 4.54 & 4194 & 0.69 & 2.96 & 4.02 \\
\hline 80 & Education and training & 3257 & 3.62 & 2.81 & 2518 & 0.77 & 1.58 & 1.91 \\
\hline
\end{tabular}


Table 16 (continued)

\begin{tabular}{lllllllll}
\hline CPV & Sector & $\begin{array}{l}\text { Total } \\
\text { number of } \\
\text { contracts }\end{array}$ & $\begin{array}{l}\text { Average } \\
\text { number of } \\
\text { offers }\end{array}$ & $\begin{array}{l}\text { Average } \\
\text { number of } \\
\text { SME offers }\end{array}$ & $\begin{array}{l}\text { Total number } \\
\text { of contracts } \\
\text { won byEs }\end{array}$ & $\begin{array}{l}\text { SME } \\
\text { win ratio }\end{array}$ & $\begin{array}{l}\text { Percentage } \\
\text { of contracts } \\
\text { (with SME } \\
\text { information) }\end{array}$ & $\begin{array}{l}\text { Percentage of } \\
\text { contracts } \\
\text { (all contracts) }\end{array}$ \\
\hline 85 & Health and social work & 2660 & 10.00 & 6.31 & 1578 & 0.59 & 1.29 & 3.36 \\
90 & Sewage and environmental services & 8601 & 4.02 & 2.51 & 5958 & 0.69 & 4.18 & 4.38 \\
92 & Recreational and sporting & 495 & 5.86 & 4.61 & 377 & 0.76 & 0.24 & 0.40 \\
98 & Other community services & 736 & 3.25 & 2.63 & 537 & 0.73 & 0.36 & 0.42 \\
\hline
\end{tabular}

Source: TED Database

Open Access This article is licensed under a Creative Commons Attribution 4.0 International License, which permits use, sharing, adaptation, distribution and reproduction in any medium or format, as long as you give appropriate credit to the original author(s) and the source, provide a link to the Creative Commons licence, and indicate if changes were made. The images or other third party material in this article are included in the article's Creative Commons licence, unless indicated otherwise in a credit line to the material. If material is not included in the article's Creative Commons licence and your intended use is not permitted by statutory regulation or exceeds the permitted use, you will need to obtain permission directly from the copyright holder. To view a copy of this licence, visit http://creativecommons.org/licenses/by/4.0/.

\section{References}

Acemoglu, D., Akcigit, U., Bloom, N., \& Kerr, W. R. (2018). Innovation, reallocation, and growth. American Economic Review, 108(11), 3450-3491.

Ancarani, A., Di Mauro, C., Hartley, T., \& Tünde Tátrai, T. (2019). A comparative analysis of SME friendly public procurement: Results from Canada, Hungary and Italy. International Journal of Public Administration. https://oi. org/10.1080/01900692.2019.1575853.

Aschoff, B., \& Sofka, W. (2009). Innovation on demand-Can public procurement drive market success of innovations? Research Policy, 38, 1235-1247.

Ayyagari, M., Beck, T., \& Demirgüç-Kunt, A. (2007). Small and medium enterprises across the globe. Small Business Economics, 29, 415-434.

Baldi, S., Bottasso, A., Conti, M., \& Piccardo, C. (2016). To bid or not to bid, that is the question: Public procurement, project complexity and corruption. European Journal of Political Economy, 43, 89-106.

Bates, T., Bradford, W., \& Seamans, R. (2018). Minority entrepreneurship in twenty-first century America. Small Business Economics, 50(3), 415-427.

Beck, T., \& Demirgüç-Kunt, A. (2006). Small and medium-size enterprises: Access to finance as a growth constraint. Journal of Banking \& Finance, 2931-2943.
Blind, K., Pohlisch, J., \& Rainville, A. (2020). Innovation and standardization as drivers of companies' success in public procurement: An empirical analysis. Journal of Technology Transfer, 45, 664-693.

Conley, T. G., Hansen, C. B., \& Rossi, P. E. (2012). Plausibly exogenous. Review of Economics and Statistics, 94(1), 260272.

Coviello, D., \& Mariniello, D. (2014). Publicity requirements in public procurement: Evidence from a regression discontinuity design. Journal of Public Economics, 109, 76-100.

Dennis Jr., W. J. (2011). Entrepreneurship, small business and public policy levers. Journal of Small Business Management, 49, 92-106.

Djankov, S., Ghossein, T., Islam, A. M., \& Saliola, F. (2017). Public procurement regulation and road quality. World Bank Policy Research Working Paper, 8234. Washington D.C.: World Bank.

Edler, J., \& Georghiou, L. (2007). Public procurement and innovation-Resurrecting the demand side. Research Policy, 36, 949-963.

Edler, J., \& Yeow, J. (2016). Connecting demand and supply: The role of intermediation in public procurement of innovation. Research Policy, 45, 414-426.

European Commission. (2008). European code of best practices facilitating access by SMEs to public procurement contracts (p. 2193). Brussels: SEC https://www.ecec. net/fileadmin/user_upload/smecodeofbestpracticesen1.pdf.

European Commission. (2019). Public procurement indicators 2017. Brussels: DG GROW.

European Union. (2014). "Directive 2014/24/EU of the European Parliament and of the Council of 26 February 2014 on public procurement and repealing Directive 2004/18/EC," Official Journal L94/65. At: https://eur-lex.europa.eu/legalcontent/EN/TXT/?uri=celex\%3A32014L0024.

Evenett, S., \& Hoekman, B. (2005). Government procurement: Market access, transparency, and multilateral trade rules. European Journal of Political Economy, 21(1), 163-183.

Fadic, M. (2020). Letting luck decide: Government procurement and the growth of small firms. Journal of Development Studies, 56(7), 1263-1276.

Fairlie, R., \& Marion, J. (2012). Affirmative action programs and business ownership among minorities and women. Small Business Economics, 39, 319-339. 
Ferraz, C., Finan F. \& Szerman D. (2015). "Procuring firm growth: The effects of government purchases on firm dynamics," NBER Working Paper No. 21219.

Geroski, P. (1990). Procurement policy as a tool of industrial policy. International Review of Applied Economics, 4(2), 182-198.

Glas, A., \& Eßig, M. (2018). Factors that influence the success of small and medium-sized suppliers in public procurement: Evidence from a centralized agency in Germany. Supply Chain Management, 23(1), 65-78.

Harland, C., Telgen, J., Callender, G., Grimm, R., \& Patrucco, A. (2019). Implementing government policy in supply chains: An international coproduction study of public procurement. Journal of Supply Chain Management, 55, 6-25.

Hoekman, B., \& Sanfilippo, M. (2019). Foreign participation in public procurement and firm performance. Review of World Economics, 156(1), 43-71.

Kenny, C. \& Crisman B. (2016). Results through transparency: Does publicity Lead to better procurement? Center for Global Development Working Paper 437. Washington D.C.: Center for Global Development.

Knack, S., Biletska, N., \& Kacker, K. (2019). Deterring kickbacks and encouraging entry in public procurement markets: Evidence from firm surveys in 90 developing countries. World Bank Economic Review. https://doi.org/10.1093 /wber/lhy016.

Krasnokutskaya, E., \& Seim, K. (2011). Bid preference programs and participation in highway procurement auctions. American Economic Review, 101(6), 2653-2686.

Kutlina-Dimitrova, Z., \& Lakatos, C. (2016). Determinants of direct cross-border public procurement in EU member states. Review of World Economics, 152(3), 501-528.

Lewbel, A. (2012). Using heteroscedasticity to identify and estimate mismeasured and endogenous regressor models. Journal of Business and Economic Statistics, 30, 67-80.

Lewbel, A. (2018). Identification and estimation using heteroscedasticity without instruments: The binary endogenous regressor case. Economics Letters, 165(April), 10-12.

Li, T., \& Zheng, X. (2009). Entry and competition effects in firstprice auctions: Theory and evidence from procurement auctions. Review of Economic Studies, 76(4), 1397-1429.

Loader, K. (2011). Are public sector procurement models and practices hindering small and medium suppliers? Public Money \& Management, 31(4), 287-294.

Loader, K. (2015). SME suppliers and the challenge of public procurement: Evidence revealed by a UK government online feedback facility. Journal of Purchasing and Supply Management, 21(2), 103-112.

Marion, J. (2007). Are bid preferences benign? The effect of small business subsidies in highway procurement auctions. Journal of Public Economics, 97(7-8), 1591-1624.
Marion. (2011). Affirmative action and the utilization of minorityand women-owned businesses in highway procurement. Economic Inquiry, 49(3), 899-915.

Nakabayashi, J. (2013). Small business set-asides in procurement auctions: An empirical analysis. Journal of Public Economics, 100, 28-44.

Nielsen, W. (2017). Technical report: Policies that promote SME participation in public procurement. Business Environment Working Group (Donor Committee for Enterprise Development). Paris: OECD. At: https://www.enterprisedevelopment.org/wp-content/uploads/DCED-BEWG-SMEProcurement-Report.pdf.

OECD (2018). "SMEs in public procurement: Practices and strategies for shared benefits," OECD Public Governance Reviews, https://www.oecd.org/publications/smes-inpublic-procurement-9789264307476-en.htm.

Porter, M. (1990). The competitive advantage of nations. New York: Free Press.

Shelton, L., \& Minniti, M. (2018). Enhancing product market access: Minority entrepreneurship, status leveraging, and preferential procurement programs. Small Business Economics, 50(3), 481-498.

Stake, J. (2017). Evaluating quality or lowest price: Consequences for small and medium-sized enterprises in public procurement. Journal of Technology Transfer, 42, 1143-1169.

Stam, E., \& van de Ven, A. (2019). Entrepreneurial ecosystem elements. Small Business Economics. https://doi.org/10.1007 /s11187-019-00270-6.

Taş, B. K. O. (2020). Effect of public procurement regulation on competition and cost-effectiveness. Journal of Regulatory Economics. https://doi.org/10.1007/s11149-020-09409-w.

Timmermans, B., \& Zabala-Iturriagagoitia, J. M. (2013). Coordinated unbundling: A way to stimulate entrepreneurship through public procurement for innovation. Science and Public Policy, 40(5), 674-685.

Trybus, M., \& Andrecka, M. (2017). Favouring small and medium-sized enterprises with Directive 2014/24/EU? European Procurement \& Public Private Partnership Law Review, 12(3), 224-238.

UNCITRAL. (2014). Model law on public procurement. Vienna: UNCITRAL Secretariat.

World Bank. (2017). Benchmarking public procurement: Assessing public procurement regulatory systems in 180 economies. Washington, DC: World Bank.

Publisher's note Springer Nature remains neutral with regard to jurisdictional claims in published maps and institutional affiliations. 